This item was submitted to Loughborough's Research Repository by the author.

Items in Figshare are protected by copyright, with all rights reserved, unless otherwise indicated.

\title{
Designed to be employed? Measuring the impact of a multidisciplinary collaborative design project on learner perceptions of employability attributes
}

PLEASE CITE THE PUBLISHED VERSION

https://www.routledge.com/Online-Learning-for-STEM-Subjects-International-Examples-of-

Technologies/Childs-Soetanto/p/book/9781138934443

\section{PUBLISHER}

(CTaylor \& Francis (Routledge)

\section{VERSION}

AM (Accepted Manuscript)

\section{PUBLISHER STATEMENT}

This work is made available according to the conditions of the Creative Commons Attribution-NonCommercialNoDerivatives 4.0 International (CC BY-NC-ND 4.0) licence. Full details of this licence are available at: https://creativecommons.org/licenses/by-nc-nd/4.0/

\section{LICENCE}

CC BY-NC-ND 4.0

\section{REPOSITORY RECORD}

Soetanto, Robby, Mark Childs, Paul Poh, Jacqueline Glass, Stephen Austin, Zulfikar A. Adamu, and Chinwe Isiadinso. 2019. "Designed to Be Employed? Measuring the Impact of a Multidisciplinary Collaborative Design Project on Learner Perceptions of Employability Attributes”. figshare. https://hdl.handle.net/2134/23065. 


\section{Designed to be employed? Measuring the impact of a multidisciplinary collaborative design project on learner perceptions of employability attributes}

Robby Soetanto, Mark Childs, Paul S.H. Poh, Jacqueline Glass, Stephen Austin, Zulfikar A. Adamu, Chinwe Isiadinso

\section{Introduction}

A collaborative building design project undertaken within an internationally-distributed team involves a dynamic process, characterised by generation and sharing of information, and synthesis of knowledge between participants. Learning within this dynamic environment is challenging, but can bring a number of notable benefits for the participants. Inherent within successful collaborative learning is the required ability to co-produce design 'content' with others from different disciplines, and to manage the 'relationship' between all participants involved in the design team (Leinonen et al., 2005). The 'content' constitutes individuals' inputs, which originate from disciplinary knowledge, skills and expertise, whereas managing the relationship requires a set of 'soft' people management skills. During the design process, the participants are presented with a problem (in a building project, it is usually a client brief), which has multiple potential solutions. To arrive at an optimum solution, the participants should explore the rationale of each alternative, and present and negotiate alternatives with the other participants. This process encourages deep-learning of the subject discipline and helps to develop people management skills, such as teamwork, communication, and other performance-enhancing behaviours which have been linked to 'proactive personality' (Tymon 2013). In the present and future labour market, graduates are expected to be able to work across disciplinary and geographical boundaries (BecerikGerber et al. 2012, BIM2050 group 2014), and these people management skills have been identified as the skills for developing sustainable built environment (BE) (Egan 2004). In a report commissioned by the UNESCO, Beanland and Hadgraft (2014) further stressed the importance of the development of appropriate interpersonal attributes and capabilities as an integral part of engineering education worldwide.

The evaluation of the skills developed from the learning activity is critical to demonstrate the success of learning endeavour, and is reflected in the achievement of learning outcomes. There exist examples which explore and evaluate the impacts and benefits of collaborative design projects in the built environment (e.g. Becerik-Gerber et al. 2012), but none evaluate pedagogical and personal development skills from the learner perspective, and then 
compare the developed skills before and after a learning intervention. This evaluation is presented in this chapter, with a view to enhance understanding of the effectiveness of this learning approach, and to inform key requirements of its successful implementation.

This chapter considers several issues in the evaluation of collaborative design project, including measures which allow consistency of evaluation of pre- and post-implementation across several disciplines involved in the collaboration, learning outcomes of each discipline, and the influence of the participants' beliefs about the benefits of collaborative design project.

Thus, key research questions are suggested as follows.

1. What are the impacts of a collaborative design project on learning outcomes, defined by attributes including understanding, ability, skills and qualities, as perceived by the participants, pre- and post-implementation?

2 . Is there any difference in perceived impact between participants from different disciplines, and those with different beliefs about the efficacy of the learning approach?

3. What attributes can facilitate successful collaborative design?

In the BIM-Hub project, the participating students were asked to rate their perceived ability against a range of understanding, ability, skills and qualities, defined as attributes at the start and on completion of the project. Data were obtained from 139 completed pre- and post-implementation questionnaires. The following sections review key literature related to building design projects and evaluation of key skills requirements, before the detailed approach and research methods are explained. The findings are then presented and discussed. Conclusions are drawn to address the above research questions.

\section{Evaluation of building design project and key skills requirements}

The implementation of collaborative learning is believed to bring additional benefits of promoting 'soft' people management, employability skills, motivating and improving student engagement. Several studies, such as Thloaele et al. (2015) provided evidence that technology-enhanced, cooperative group-project learning enhances academic performance. However, an evaluation of students' perceived skills resulting from working in a virtual collaborative design in BE disciplines is scant. This is rather surprising given that the idea of a 
collaborative design project is not new. Most published papers discussed the evaluation from the tutor perspective, highlighting the development of interpersonal skills (e.g. Becerik-Gerber et al., 2012). Selected published findings from the evaluation of collaborative design work are discussed in the following paragraphs.

O’Brien et al. (2003) examined student self-assessment of collaboration in a virtual, multidisciplinary design project between two universities. The results suggest that most students felt that the groups performed efficiently and produced high quality designs. Some $20 \%$ of the students responded neutrally or negatively about the experience due to the difficulties encountered during the collaborative process. Individual critiques revealed that the difficulties stemmed from cultural differences between group members, rather than from technologies or distance between team members. There was no evaluation of skills gained from the collaborative design exercise.

Tucker and Rollo (2006) reported on their experience of running collaborative design module over three academic years. They found that the performance of participating students was higher than that of non-participating. Lessons learnt from the previous years provided considerations for changing student grouping strategies, which had brought performance improvement for the whole cohort. This is inconsistent with the assessment results reported by Soetanto et al. (2014) who suggested that the collaborative design project has no impact on individual and group marks, but it does develop a proactive attitude among the participating students, highlighting 'proactive personality' coined by Tymon (2013).

Bhandari et al. (2011) developed a multidisciplinary course on sustainable engineering design. They found that participating students felt that their ability to consider technical, environmental and social aspects of sustainability in development of engineering design solutions improved. From interviews with students participating in an integrated sustainable design experience, Wolcott et al. (2011) found that the students gained improved communication and teamwork skills. Stanford et al. (2013) statistically analysed student self-rated response of eight relevant sustainability concepts from pre-and postimplementation of a capstone sustainable design project. The analysis revealed significantly improved knowledge in 6 out of 8 sustainability areas including economic analysis, sustainability rating systems, impact on society, life cycle assessments, sustainable transportation and sustainable materials. Further qualitative analysis of students' journals confirmed improved critical thinking skills. Korkmaz (2012) analysed qualitative responses of a pre- and post-case study assignment survey to evaluate the effect on student learning. 
The analysis showed that case-based collaborative-learning methods improved student learning about the delivery of sustainable building attributes.

Becerik-Gerber et al. (2012) discusses the learning outcome of virtual collaborative design based on several primary sources, including a student satisfaction survey, a series of survey completed by students at the end of each assignment, official course evaluations, formal/ informal discussions with students, and instructors' evaluation of students' work. From the student survey alone, they found that modelling and virtual collaboration skills have adversely impacted their experience, and there was disparity between skills levels and abilities of students from each institution. Although they preferred to have in-person than virtual meetings, a virtual design project improves the learning of collaborative building information modelling (BIM) concepts.

Solnosky et al. $(2013,2014)$ developed a multidisciplinary architectural engineering capstone design course to enhance student skills to work within integrated project delivery (IPD) and BIM environment. They mapped the 'short-term' educational objectives of the course against the educational outcomes, which are defined as noticeable traits that can be seen for up to five years after taking the course. The assessment of objectives and outcomes was undertaken by faculty members and industry practitioners. There is no evidence of student evaluation of the skills developed from the course.

Most evaluations were conducted by asking the experience of students, providing qualitative responses. The impact of the learning approaches on the participant attributes following implementation has not been fully assessed quantitatively. Despite a lack of consensus, several studies suggested perceived skills improvement, but it is unclear which skills and why they have been improved. For only a few comparisons between pre- and post-implementation (such as Stanford et al. 2013, on student knowledge of sustainability), evaluation was based on the knowledge gained, rather than transferable skills and attributes, and was based on limited samples ( $n=19$ for pre- and $n=15$ for postimplementation in Stanford et al. 2013). Most design projects (as discussed above) are not based on virtual collaboration, with exception of Becerik-Gerber et al. (2012). Given the variability of implementations, lessons learnt are not directly applicable and comparable for a different context (Soetanto et al. 2014). As there is a lack of longitudinal research, there is no control group to benchmark the skills improvement, and it is not possible to test the learners' skills in their professional life. 


\section{Learning outcomes of collaborative design}

Assessment is an essential part of learning, and determines how and what the students learn. To promote deep learning, the assessment tasks are designed to test whether the students have met these learning outcomes (Biggs 1996, Ayres 2015). A collaborative design project is built on a constructivist approach to learning, where the students build on their existing knowledge through the exploration of the subject, sharing and discussing their findings and ideas with the other group members (Vygotsky 1978 c.f. Ayres 2015). The students take responsibility for their own learning by actively undertaking learning activities, such as searching, exploring and sharing information with others, problem solving, and discussing problems in their group. These activities developed higher-order thinking skills, such as analysis, synthesis and evaluation (Ayres 2015). A collaborative learning process is seen as a means to achieve learning outcomes, and should be considered as an important element in the assessment of the learning. Thus, the challenge is to develop an appropriate means to assess an individual's learning within a collaborative learning context.

The assessment of collaborative learning is different from that of individual learning because the learning occurs with a group environment. The assessment of individual learning with a collaborative learning context is found to be challenging due to the difficulty in completely separating the learning environment (i.e. the project, team dynamic) from individual student learning (Howard 2014). The group working process and team dynamic can determine what individual members learn and achieve at the end. The final grade attainment of the group may not have any relationship with individual achievement. Thus, there may be cases where the group grade is high, but the individual only achieves a satisfactory level of learning. This may be because members try hard to maximise their group grade to the detrimental of individual learning gain. In engineering education, quantitative assessment methods (such as exams) are a common way to assess summative learning of individual students, but these can lead to competitive and mark-chasing behaviours which do not really promote deep learning. Howard (2014) suggests that assessment of individual learning in a group environment should be undertaken via qualitative methods, such as portfolio and presentation.

Group work develops students' confidence to be an independent learner, through taking responsibility for their own learning. It permits the students to develop their people management skills and an independent attitude, and provides a sound platform to develop their knowledge, understanding, skills for subsequent years. Here, a successful outcome does not entirely rely on the technical prowess of individual members, but depends on the 
ability of the team to work together and integrate the work into a coherent piece. This is the very skills that are in high demand by the industry, and hence a group assignment helps to develop employability skills (Ayres 2015).

To determine what the students should achieve from collaborative learning activities, we need to consider the perspectives of multiple stakeholders (Tymon 2013). Here, the needs of employers are, perhaps, one of the most important, and have often been the aim of educational institutions. The term, employability skills, has been used to describe the skills that make graduates to be employable at the end of their study. Tymon (2013) argued the emphasis of employability should be on the 'ability', rather than 'employment' or 'being employed'. The first term encompasses a larger scope of developing learning activities to equip graduates with enabling long-life skills to contribute to society at large. In practical terms, employability skills are often meant to include whole range of skills which make graduates more employable. Some argue the need to have other people management skills on top of the technical skills (BIM2050 group 2014). Although it is rather contentious, the current discourse suggests that employability skills are the skills that give graduates a competitive advantage in the job market. Given the diversity of perspectives regarding the knowledge and skills of collaborative learning, a standard to assess the learning outcomes could help stakeholders to focus on important aspects of learning activities. For example, educators would be able to design learning methods, activities and assessment which address the outcomes. Standard learning outcomes could also raise learners' awareness of the expectations of the programme. In BE education, such standards are typically set by professional bodies, and used in the accreditation of degree programmes. Due to multiple disciplines involved in a collaborative design, however, a review of international standards of relevant disciplines is provided in the following sections.

\subsection{Engineering education standards}

Standards in engineering education have received significant attention due to increasing perceived need to redefine the future education needs of practicing engineers, who are able to contribute to the society (Beanland and Hadgraft 2014). Emerging issues and challenges, such as sustainability and climate change, have provided an impetus to broaden the scope of engineering education in order to equip the future engineers with relevant knowledge and skills to undertake their changing roles. Through accreditation, professional institutions have an important and influential role to specify the knowledge, skills and behaviours that graduates should be able to demonstrate on the completion of programmes (Beanland and 
Hadgraft 2014). Hence, the learning outcomes of relevant professional institutions are described here.

An international standard for engineering education was developed by the International Engineering Alliance via the Washington Accord Agreement. The agreement is binding to the signatories' countries. It provides a professional competencies' profile and graduate attributes associated with each of three categories of employment in engineering, i.e. Professional Engineers, Engineering Associates, and Engineering Technicians. Graduate attributes are met when a student completes an accredited engineering degree programme. Professional competencies profile should be fulfilled five years later when the individual looks to apply for professional engineering registration (Beanland and Hadgraft 2014). The Accord stipulates that two fundamental objectives of engineering education are to build a 'knowledge base' and 'attributes' of the graduates to continue learning and develop competencies required for independent practice. The Accord sets a minimum standard which graduates from any accredited engineering degree programme should achieve by the end of their study. Perhaps the significance of the Accord is to provide assurance that graduates from accredited programmes from signatory countries could operate together in a project team.

\subsection{Construction management education standard - the Chartered Institute of Building (CIOB)}

In the UK, standard of construction management education is based on the $\mathrm{CIOB}$ education framework (CIOB 2013). The framework provides guidance to teaching institutions to review the existing programme content, a reference document when designing a new programme, and importantly, for gaining accreditation for the programme. Although it is not meant to be prescriptive document, the $\mathrm{CIOB}$ accreditation is based on an education framework and provides an approval that teaching institutions or programmes have met the highest standard of quality in construction management education. The education framework was developed based on UK Quality Assurance Agency benchmarks and National Occupational Standards. The framework is applicable to four educational levels from diploma to postgraduate programmes. Learning outcomes of the education framework are grouped under six main themes, namely sustainability, construction environment, construction management, construction technology, health, safety and welfare, and ethics and professionalism. They are further detailed in sub-themes, and mapped against educational levels. 
Although the skills and attributes associated with collaborative design are not obvious from the main themes, there are some detailed items which underpin knowledge and behaviour to work in collaborative design, including 'team and integrated teams', 'Building Information Modelling (BIM)', 'respect for other professions and their roles', and 'internationalisation'.

\subsection{Architectural education standard - Canadian Architectural Certification Board (CACB) and Royal Institute of British Architects (RIBA)}

Accreditation of architectural education in Canada is undertaken by the Canadian Architectural Certification Board (CACB 2012). The board stipulates 31 student performance criteria which define the skills and knowledge for all graduates of an accredited degree programme. The criteria are organised according to four categories, namely 'critical thinking and communication', 'design and technical skills', 'comprehensive design', and 'leadership and practice'. Several relevant criteria for a collaborative design project include 'collaborative skills' and 'leadership and advocacy'. Both determine the skills to work collaboratively with other disciplines in a project and maximise outcomes through these skills.

The accreditation of architectural courses in the UK is undertaken by RIBA via its Education Department (RIBA 2014). RIBA (2014) stipulates that students in accredited architectural course should be able to demonstrate graduate attributes at parts 1 and 2, before Professional Practice Examination in Architecture (part 3). Similar to CACB's attributes, several attributes are relevant to a collaborative design project, summarised as: 'knowledge of professional inter-relationship of parties', 'ability to apply a range of communication methods and media', 'knowledge of context and industry', 'professional quality and problem solving skills', 'professional judgement', and 'ability to take the initiative and make appropriate decisions', 'skills necessary to plan project-related tasks', and 'coordinate and engage in design team interaction'.

\subsection{BIM learning outcomes}

The UK's BIM Academic Forum (BAF 2013) established learning outcomes from BIM learning. The learning outcomes are grouped in three main categories, namely 'knowledge and understanding' (including principles and concepts of BIM), 'practical skills' (ability to use BIM software, e.g. Revit), and 'transferable skills' (including collaborative working, 
communication in multidisciplinary team). The categories are cross-referenced against educational levels from first to final years of undergraduate and postgraduate programmes. This sets an expectation of what each level should achieve for each category.

At year one (level 4) of undergraduate study, the learning outcomes are to provide the context and background to the industry, emphasising students to appreciate the manner in which the industry works, the roles and disciplines involved, to introduce how information is prepared, shared and issued, and technologies to support BIM and promote collaborative working. For year two (level 5), the learning outcomes are to develop the knowledge and understanding of the role of BIM as a business driver for collaborative working within an integrated supply chain. Year 3 (level 6) learning outcomes should focus on building competencies and knowledge around people, systems and process of BIM. The students should develop an awareness and appreciation of the cultural and organisational impacts of $\mathrm{BIM}$, an appreciation of new ways of integrated team work and collaborative working environments (BAF 2013).

In summary, the review above suggests different standard learning outcomes across different BE disciplines. It is worth noting that all recognise the essential attributes required for collaboration in project team. Given that activities in collaborative learning are selfregulatory, the perceived learning gain may be influenced by the participants' belief that working on collaborative design project will improve their attributes. The underpinning theory is explained in the following section.

\section{Self-efficacy theory}

Self-efficacy is a theory in educational psychology, which focuses on establishing a relationship between learners' belief of what they can achieve and the outcomes of learning. Bandura (1977) first coined self-efficacy belief as an important attribute of performance in learning. He defined perceived self-efficacy as personal judgments of one's capabilities to organise and execute courses of action to attain designated goals. Self-efficacy is a multidimensional concept in itself, but also relates to other concepts such as outcome expectation, self-concept and perceived control, nevertheless self-efficacy focuses principally on a specific task that learner is going to undertake (Zimmerman 2000). Selfefficacy belief was found to be a significant predictor of academic performance, and was positively correlated with motivation, participation, persistence, and the amount of effort. Self-efficacious students tend to be more proactive and take initiative in their group learning 
(i.e. self-regulated learning, defined by Bandura 1977). Given that the activities involved in collaborative design project are self-regulatory, there is potential impact of self-efficacy belief on the evaluation of learning outcomes. This was considered in this research by asking participating students whether they believe that working on a collaborative design project will enhance their attributes. The purpose is to identify whether having self-efficacy belief will impact on the evaluation pre- and post-implementation.

\section{Methods}

\subsection{Attributes of knowledge, understanding, ability, skills and qualities}

The engineering subject benchmark contains statements for knowledge, understanding, ability, skills and qualities that were considered necessary to enable graduates to work effectively in their professional career (Maddocks et al 2002). They were subsequently termed 'attributes'. Although they were the benchmark for engineering degree programme, the attributes contained within are reasonably general to be adapted for evaluating achievement of students participating in a collaborative design project. The intention was to cover as many attributes as possible within the subject benchmark, because collaborative design can potentially contribute to the development of a range of graduate attributes. However, 'ability to use laboratory and workshop equipment to generate valuable data' was removed as it was deemed to be not relevant. The number of attributes included in the questionnaire was considered to be reasonable for a short (10-15 minutes) completion, but also sufficient to allow an evaluation of wider range of learning gains afforded by collaborative design project. The attributes representing skills, abilities and qualities are categorised under five headings:

- Knowledge and Understanding

- Intellectual Abilities

- Practical Skills

- General Transferable Skills

- Qualities

Before their inclusion in the questionnaire, the statements were adapted to more concrete terms to make them more relevant and allow participating students to effectively consider 
them within the collaborative design project. The attributes are listed in the second column of Table 1.

\subsection{Questionnaire design and distribution}

Participating students were asked to indicate their assessment of their ability for each attribute using a scale from 1 to 4, where 1 indicates 'poor', 2 'moderate', 3 'good' and 4 'very good'. They were also asked to indicate their perception whether working in collaborative design project would improve their achievement on each attribute. They indicated their opinion through a binary answer, 'yes' or 'no'. The responses allow an exploration of the impact of self-efficacy belief on the learning gain in a collaborative design project. For both questions on attributes and perceived benefits, 'do not know' answer was provided. The questionnaire simply lists the statements without headings as this presentation prevents the students giving the same rating to attributes in the same heading. Following completion of questionnaire design, human participant ethical approval was obtained.

Questionnaires were distributed and collected by hand in the class, firstly in the second week and secondly in the penultimate week of their involvement with the activity. The participating students were given about 10 to 15 minutes to complete the questionnaire.

\subsection{Analysis of data}

Data from the completed questionnaires were coded and inputted into SPSS version 22. Preand post-implementation scores were averaged and the discrepancies between them calculated. The discrepancies indicate the amount of improvement in student ability before and after participating in the project. They were then ranked in descending order of magnitude, as presented in Table 4.1, column 6. To confirm the difference between pre- and post-implementation scores, the data were subjected to independent samples t-test. The grouping (independent) variable was stages (pre- and post-implementation), the test (dependent) variable was the score of each attribute. The t-test yielded probability ( $p$-value) of obtaining the results due to sampling error if there was no difference between pre- and post-implementation scores. The threshold for confirming the difference (level of significance) was set at $5 \%$, deemed to be appropriate for quantitative data analysis in social 
science, and applicable to statistical analysis presented in this chapter. The p-value for each attribute is presented in Table 4.1, column 7.

<insert table 4.1>

The scores were subjected to analysis of variance (ANOVA) to identify any differences of scores between discipline groups (architect, civil/structural engineer, construction manager, postgraduate project manager). The results are presented in Table 4.1, column 8. A two-way ANOVA was employed to identify interaction between stages and discipline groups, and stages and perceived benefit of the project, on the scores. The interaction between stages and perceived benefit investigated whether the scores of perceived ability in the pre- and post-implementation were influenced by the perceived benefit of participating in the collaborative design project. It is hypothesised that those students who perceive that working in collaborative design project is going to help them improve their performance will perceive higher performance in the post-implementation. The interaction between stages and discipline groups investigated whether the scores of perceived ability in the pre- and post-implementation were influenced by their membership in discipline groups. In other words, it investigated whether the perceived level of performance pre- and postimplementation is the same, or otherwise, across different discipline groups. The test of the interactions was conducted to only those attributes with statistically significant (in the ttests and ANOVA tests) because they are considered worthy of further investigation. The results of two-way ANOVA are provided in Table 4.1, columns 9 and 10.

Principal component analysis (PCA) was used to explore the grouping of required attributes to support a successful collaborative design project. The use of PCA rests on the assumption that the attributes would cause or produce the components (rather than that the components cause attributes), hence the exploratory nature of the analysis. The KaiserMeyer-Olkin measure of sample adequacy of 0.912 and Bartlett's test of sphericity with $p<0.0005$ indicate that there are correlations between attributes, and so PCA can be meaningfully applied. The number of components was determined based on the number of components that have an Eigen value of more than one. This was supported by the observation of the scree plot. Oblique rotation (Promax with kappa of 4) was adopted based on the assumption that groups of attributes are likely to be inter-related in a real context (Male et al. 2011). Promax with kappa of 4 was applied with the intention that it can facilitate a clear grouping of attributes in to their components. The finding is summarised in Table 4.2. 
<insert table 4.2>

\section{Findings and discussion}

\subsection{Perceived achievement before and after the implementation of collaborative design, and in discipline groups}

Table 4.1 (columns 3-6) presents the average scores pre- and post-implementation, the differences between pre- and post-implementation average scores, and the ranking of the most improved scores. The differences between pre- and post-implementation scores show that all but one of the attributes have been perceived to be improved after participation in the collaborative design project. This is a positive outcome, endorsing the benefit of learning through a collaborative design project. 'Ability to use Information Technology effectively', 'Independent of mind, with intellectual integrity, particularly in respect of ethical issues', 'Analytical in the formulation and solutions of problems' were the three most improved attributes, followed by 'Ability to demonstrate understanding of the impact of construction/ engineering solutions on society' and 'Ability to solve engineering and design problems through creative and innovative thinking' as joint fourth ranked. These improvements were confirmed by a t-test as presented in Table 4.1, column 7, which indicated that the difference between pre- and post-implementation average scores of all five attributes was statistically significant. The other significant attributes include 'Ability to work in a multi-disciplinary team', 'Ability to manage resources and time', and 'Ability to demonstrate understanding of external constraints', which were ranked sixth, seventh and ninth, respectively. Despite being ranked eighth, attribute 'Ability to undertake lifelong learning for continuing professional development' was not statistically significant at $5 \%$, and therefore, this result only provides some evidence of improvement in this attribute.

At the bottom of the ranking, 'Ability to demonstrate business and management techniques', 'Self-motivated', and 'Ability to apply professional judgement, balancing issues of costs, benefits, safety, and quality' were ranked the weakest three attributes. The average score of one attribute, 'ability to demonstrate business and management techniques' was found to be lower after the implementation. Perhaps, the link between the collaborative design activities and business and management technique was not clearly established. It is worth noting that 'self-motivated' was the attribute with the highest average score for both preand post-implementation. This suggests that the motivation of participating students 
remains high throughout the implementation of collaborative design project, confirming the benefit of collaborative learning for motivating and engaging students.

The results indicate that the students experienced significant improvements in their abilities to: use ICT for collaborative design tasks; deploy creative, analytical and innovative thinking to solve engineering and design problems; understand the impact of construction/ engineering solutions and any external constraints; manage their resources and time; demonstrate independence of mind with intellectual integrity. Also, having participated in the project, the students became more acquainted with working in a multi-disciplinary team, recognising the significance of leadership, and they better understood their role in a team.

The results of investigating the perceived achievement of discipline groups show that average scores were significantly different between groups (based on ANOVA tests, presented in Table 4.1, column 8). This indicates that each group perceived that they achieved differently with respect to the attributes. This finding was somewhat expected as the students may hold different views and priorities on the attributes presented to them in the questionnaire.

\subsection{Interaction between stages and perceived benefit, and stages and discipline groups}

The investigation of the interaction between stages and perceived benefit, and stages and discipline groups was conducted only on those attributes that had statistically significant values, as presented in the previous section (Table 4.1, columns 9 and 10). The results show that there is interaction between stages and perceived benefit in three attributes; 'Ability to apply mathematical, scientific and technological tools', 'Ability to use Information Technology effectively', 'Analytical in the formulation and solutions of problems'. An illustration of this interaction for 'Ability to use Information Technology effectively' is presented in Figure 4.1. The figure includes two crossing lines; one representing the students who believe the benefit of collaborative learning shows the increase of average score from pre- to post-implementation whereas the other one representing the students who do not believe the benefit shows the decrease of average score. This finding suggests that those who believe that working on a collaborative design project is going to improve these attributes, are more likely to have improved perceived achievement to these attributes; those who do not believe similarly, are more likely to not perceive any achievement (or less achievement). Thus, this finding calls for the need to reinforce learners' beliefs in the benefit and self-efficacy, early in the implementation. 
Despite significant differences in all attributes, the interaction between stages and discipline groups is only found in three attributes; 'Ability to communicate effectively, using both written and oral methods', 'Ability to use Information Technology effectively', and 'Selfmotivated'. An illustration for 'Ability to use Information Technology effectively' in Figure 4.2 demonstrates four lines with different inclination for the pre- and post-implementation scores for different disciplines. While the lines, representing Civil/structural engineers (CU), construction managers (LU) and post-graduate sustainability managers (MS) do demonstrate increasing scores in post-implementation, the line for architects (RU) shows decreasing scores. In this particular case, perhaps, the architects did not feel that they had learnt any new software, as it was realised during the implementation they already had sufficient skills to use drawing software, to the advantage of their colleagues in other institutions. Nevertheless, this finding suggests that the changes (increase or decrease) in scores are not the same for all discipline groups. One discipline group may not perceive the same benefit to that of another group.

<insert figures 4.1 and $4.2>$

\subsection{Attributes grouping and their contribution to successful collaborative design project}

The PCA has neatly grouped the attributes into four components which are interrelated (due to the use of oblique rotation) (see Table 4.2). The first component includes six attributes related to communication, teamwork and management skills both for team and personal. Self-motivation was also part of this component, and therefore the component is named 'teamwork, management and motivation.' The variance of the first component contributes $43 \%$ of the total variance. The fact that its membership covers four of eight most improved attributes confirms its importance. However, the analysis is not meant to be predictive of the improved performance.

The second component is the largest group with ten attributes. It covers a range of attributes which suggest sound underpinning basic knowledge and ability to perform a meaningful contribution to the team. This component is called 'technical knowledge for creativity and innovation', and contributes $6.3 \%$ of the total variance. The third component is formed on five attributes, mostly related to ability to assess the implications of decisions/ actions. An attribute of enthusiasm is also part of the component, which is consequently titled 'understanding implications and enthusiasm'. This component contributes $5 \%$ of the 
total variance. Four attributes related to understanding operational context are subsumed under the fourth component, which is named 'knowledge and understanding of wider context'. This component contributes $4.5 \%$ of the total variance.

This finding (as illustrated in Figure 4.3) suggests that for a successful collaborative design project, participants should possess sound technical knowledge, applied using good teamwork skills, understanding direct and wider implications of design decisions and actions with the team.

<insert figure 4.3>

\section{Conclusions}

A collaborative design project can benefit learners in BE subjects in several ways; (i) it trains the students to work in multidisciplinary, collaborative teams which is conditioned to mimic real working life, (ii) it equips the students with the skills set required for virtual/online collaborative working within globally distributed team, (iii) it equips the students with 'soft' people management skills which are believed to provide a competitive advantage in the current job market. The paper has presented an evaluation of employability attributes measured pre- and post-implementation of a collaborative design project involving students from three international institutions. Although the idea of collaborative design projects in BE education is not new, a comprehensive evaluation of the impact on employability attributes is surprisingly scant. The conclusions are addressed under three research questions:

7.1 What are the impacts of a collaborative design project on learning outcomes, defined by attributes including understanding, ability, skills and qualities, as perceived by the participants, pre-and post-implementation?

This study has revealed the positive impact of a collaborative design project with perceived improvement to all attributes (but one) following implementation. The extent of improvement varies across the attributes with most improved attributes demonstrating a statistically difference between pre- and post-implementation. 'Ability to use information technology effectively' being the most improved attribute is rather surprising. IT-mediated 
collaboration in a design project was new for most students as they learnt to use IT tools (e.g. GoToMeeting) for communication and discussed issues within a design software environment (e.g. Autodesk Revit). Having a different level of software skills can have an adverse impact of the collaboration experience as teams may rely on those (most likely architectural) students who have better skills to operate design software (Becerik-Gerber et al. 2012). In the project under consideration, this issue created imbalance in work load, raising a concern amongst participating students. In most situations, this issue is inevitable given different skills of participants in the real world, but tutors should prepare students to deal with this issue, and highlight the potential opportunity from learning new software skills. In any case, it is wise to equip students with basic software skills so that they can collaborate meaningfully online and in real-time.

\subsection{Is there any difference in perceived impact between participants from different disciplines, and those with different beliefs about the efficacy of the learning approach?}

The analysis indicates the influence of self-efficacy belief on several attributes with significant improved attributes for those who believed that participating in the design project would improve their attributes. This highlights the need for tutors to nurture confidence and self-efficacy, and communicate the benefit continuously from the start of implementation. The tutors have an important role in making positive self-efficacy belief habitual as early as possible in the learning endeavour. In group learning, peer achievement is often used as a reference to compare own performance with possible positive and negative impact on self-efficacy belief. Here, the tutors should emphasise that individual members of the group should support and complement (rather than compete with) one another's roles. Group membership should be determined based on complementary attributes so that individual members have the opportunities to contribute meaningfully to the group. The tutors can also set proximal goals in conjunction with distal goal, allowing for frequent constructive feedback on individual performance (Pajares 2002).

The interaction between stages and discipline groups is only found in three attributes. One of them is 'Ability to use information technology effectively', which was attributed to different software skills of the participating students. Considering the low number of attributes which demonstrated interaction, there is a need for further research in this area.

\subsection{What attributes can facilitate successful collaborative design?}


Although the PCA is not meant to be predictive, nor indicative of the weight of each component, the result suggests four components of required attributes for successful collaborative design. The component 'teamwork, management and motivation' is critical for successful collaborative design, given that the majority of attributes belonging to this component were the most improved attributes as perceived by participating students. The components do not only facilitate successful collaborative design, but also encourage and develop employability attributes among the participants.

\section{References}

Ayres, R. (2015) Lecturing, working with groups and providing individual support. A Handbook for Teaching and Learning in Higher Education, 4th edition, Fry, H., Ketteridge, S. and Marshall, S. (eds.), Routledge, Oxon.

Bandura, A. (1977) Self-efficacy: toward a unifying theory of behaviour change. Psychological Review, 84, 191-215.

Beanland, D. and Hadgraft, R. (2014) Engineering education: transformation and innovation. A monograph commissioned by UNESCO, RMIT University Press.

Becerik-Gerber, B., Ku, K., \& Jazizadeh, F. (2012). BIM-enabled Virtual and Collaborative Construction Engineering and Management. Journal of Professional Issues in Engineering Education and Practice, 138(3), 234-245.

Bhandari, A., Ong, S.K., \& Steward, B.L. (2011). Student Learning in a Multidisciplinary Sustainable Engineering Course. Journal of Professional Issues in Engineering Education and Practice, 137(2), 86-93.

Biggs, J.B. (1996) Enhancing teaching through constructive alignment. Higher Education, 32, 1-18. 
BIM2050 group (2014). Built Environment 2015: A Report on Our Digital Future. London: Construction Industry Council.

CACB (2012) Conditions and terms for accreditation for professional degree programs in architecture. The Canadian Architectural Certification Board, Ottawa, Canada.

CIOB (2013) The education framework for undergraduate programmes. The Chartered Institute of Building, Berkshire.

Egan J (2004) Skills for Sustainable Communities. Office of the Deputy Prime Minister, London, UK.

Howard, P. (2014) Assessment in PBL environment. In Beanland, D. and Hadgraft, R., Engineering education: transformation and innovation. A monograph commissioned by UNESCO, RMIT University Press.

Korkmaz, S. (2012). Case-based and Collaborative-learning Techniques to Teach Delivery of Sustainable Buildings. Journal of Professional Issues in Engineering Education and Practice, 138(2), 139-144.

Leinonen, P., Järvelä, S., \& Häkkinen, P. (2005). Conceptualizing the Awareness of Collaboration: A Qualitative Study of a Global Virtual Team. Computer Supported Cooperative Work, 14, 301-322.

Maddocks, A.P., Dickens, J.G. and Crawford, A.R. (2002) Encouraging lifelong learning by means of a web-based personal and professional development tool. ICEE, UMIST, Manchester, 18-22 August.

Male, S.A., Bush, M.B. and Chapman, E.S. (2011) An Australian study of generic competencies required by engineers. European Journal of Engineering Education, 36, 2, 151-163. 
O'Brien, W., Soibelman, L., \& Elvin, G. (2003). Collaborative Design Processes: An Active- and Reflective-learning Course in Multidisciplinary Collaboration. Journal of Construction Education, 8(2), 78-93.

Pajares, F. (2002) Gender and perceived self-efficacy in self-regulated learning. Theory into Practice, 41(2), 116-125.

RIBA (2014) RIBA procedures for validation and validation criteria for UK and international courses and examinations in architecture. Royal Institute of British Architects, London.

Soetanto, R., Childs, M., Poh, P., Austin, S., \& Hao, J. (2014). Virtual Collaborative Learning for Building Design. Proceedings of the Institution of Civil Engineers - Management, Procurement and Law, 167, MP1, 25-34. http://dx.doi.org/10.1680/mpal.13.00002

Solnosky, R., Parfitt, M.K., and Holland, R. (2013) IPD and BIM-focused capstone course based on the AEC industry needs and involvement. Journal of Professional Issues in Engineering Education and Practice, Special Issue: Curriculum Assessment and Continuous Improvement, doi: 10.1061/(ASCE)EI.1943-5541.0000157

Solnosky, R., Parfitt, M. K., and Holland, R. (2014) Delivery methods for a multi-disciplinary architectural engineering capstone design course. Architectural Engineering and Design Management, doi:10.1080/17452007.2014.925418

Stanford, M.S., Benson, L.C., Alluri, P., Martin, W.D., Klotz, L.E., Ogle, J.H., Kaye, N., Sarasua, W., \& Schiff, S. (2013). Evaluating Student and Faculty Outcomes for a Real-world Capstone Project with Sustainability Considerations. Journal of Professional Issues in Engineering Education and Practice, 139(2), 123-133.

Tlhoaele, M., Suhre, C. and Hofman, A. (2015) Using technology-enhanced, cooperative, group-project learning for student comprehension and academic performance. European Journal of Engineering Education, DOI:10.1080/03043797.2015.1056102 
Tucker, R., \& Rollo J. (2006). Teaching and Learning in Collaborative Group Design Projects. Architectural Engineering and Design Management, 2, 19-30.

Tymon, A. (2013) The student perspective on employability. Studies in Higher Education, $38(6), 841-856$.

Vygotsky, L.S. (1978) Mind in society: the development of higher psychological processes. Harvard University Press, Cambridge, MA.

Wolcott, M., Brown, S., King, M., Ascher-Barnstone, D., Beyreuther, T., \& Olsen, K. (2011). Model for Faculty, Student, and Practitioner Development in Sustainability Engineering through an Integrated Design Experience. Journal of Professional Issues in Engineering Education and Practice, 137(2), 94-101.

Zimmerman, B.J. (2000) Self-efficacy: an essential motive to learn. Contemporary Educational Psychology, 25, 82-91. 
Table 4.2 Summarised results of principal component analysis

\begin{tabular}{|c|c|c|c|}
\hline Code & Skills/attributes/qualities: & $\begin{array}{l}\text { Component } \\
\text { loading }\end{array}$ & $\begin{array}{c}\text { Variance } \\
\text { explained (\%) }\end{array}$ \\
\hline \multicolumn{3}{|c|}{ Component 1: Teamwork, management and motivation } & 42.552 \\
\hline A16 & $\begin{array}{l}\text { Ability to communicate effectively, using both } \\
\text { written and oral methods }\end{array}$ & 0.757 & \\
\hline A17 & $\begin{array}{l}\text { Ability to use Information Technology } \\
\text { effectively }\end{array}$ & 0.683 & \\
\hline A18 & Ability to manage resources and time & 0.634 & \\
\hline A19 & Ability to work in a multi-disciplinary team & 0.841 & \\
\hline A20 & $\begin{array}{l}\text { Ability to undertake lifelong learning for } \\
\text { continuing professional development }\end{array}$ & 0.637 & \\
\hline A24 & Self-motivated & 0.733 & \\
\hline \multicolumn{3}{|c|}{ Component 2: Technical knowledge for creativity and innovation } & 6.348 \\
\hline A01 & $\begin{array}{l}\text { Ability to demonstrate sound } \\
\text { specialist/discipline knowledge }\end{array}$ & 0.631 & \\
\hline A07 & $\begin{array}{l}\text { Ability to solve engineering and design } \\
\text { problems through creative and innovative } \\
\text { thinking }\end{array}$ & 0.694 & \\
\hline A08 & $\begin{array}{l}\text { Ability to apply mathematical, scientific and } \\
\text { technological tools }\end{array}$ & 0.716 & \\
\hline A09 & $\begin{array}{l}\text { Ability to analyse and interpret data and, when } \\
\text { necessary, design experiments to gain new data }\end{array}$ & 0.688 & \\
\hline A10 & $\begin{array}{l}\text { Ability to maintain a sound theoretical } \\
\text { approach in enabling the introduction of new } \\
\text { technology }\end{array}$ & 0.623 & \\
\hline A13 & $\begin{array}{l}\text { Ability to use a wide range of tools, techniques, } \\
\text { and equipment (including software) } \\
\text { appropriate to their specific discipline }\end{array}$ & 0.677 & \\
\hline A21 & Creative, particularly in the design process & 0.811 & \\
\hline A22 & $\begin{array}{l}\text { Analytical in the formulation and solutions of } \\
\text { problems }\end{array}$ & 0.761 & \\
\hline A23 & $\begin{array}{l}\text { Innovative, in the solution of engineering } \\
\text { problems }\end{array}$ & 0.668 & \\
\hline A25 & $\begin{array}{l}\text { Independent of mind, with intellectual integrity, } \\
\text { particularly in respect of ethical issues }\end{array}$ & 0.610 & \\
\hline \multicolumn{3}{|c|}{ Component 3: Understanding implications and enthusiasm } & 5.061 \\
\hline A03 & $\begin{array}{l}\text { Ability to demonstrate business and } \\
\text { management techniques }\end{array}$ & 0.720 & \\
\hline A11 & $\begin{array}{l}\text { Ability to apply professional judgement, } \\
\text { balancing issues of costs, benefits, safety, and }\end{array}$ & 0.718 & \\
\hline
\end{tabular}




\begin{tabular}{|c|c|c|c|}
\hline & quality & & \\
\hline A12 & Ability to assess and manage risks & 0.708 & \\
\hline A15 & $\begin{array}{l}\text { Ability to develop, promote and apply safe } \\
\text { systems of work }\end{array}$ & 0.755 & \\
\hline A26 & $\begin{array}{l}\text { Enthusiastic, in the application of their } \\
\text { knowledge, understanding and skills in pursuit } \\
\text { of the practice of engineering }\end{array}$ & 0.665 & \\
\hline \multicolumn{3}{|c|}{ Component 4: Knowledge and understanding of wider context } & 4.535 \\
\hline A02 & $\begin{array}{l}\text { Ability to demonstrate understanding of } \\
\text { external constraints }\end{array}$ & 0.849 & \\
\hline A04 & $\begin{array}{l}\text { Ability to demonstrate understanding of } \\
\text { professional and ethical responsibilities }\end{array}$ & 0.617 & \\
\hline A05 & $\begin{array}{l}\text { Ability to demonstrate understanding of the } \\
\text { impact of construction/ engineering solutions } \\
\text { on society }\end{array}$ & 0.683 & \\
\hline A06 & $\begin{array}{l}\text { Ability to demonstrate an awareness of } \\
\text { relevant contemporary issues }\end{array}$ & 0.682 & \\
\hline \multicolumn{3}{|r|}{ Total } & 58.496 \\
\hline
\end{tabular}




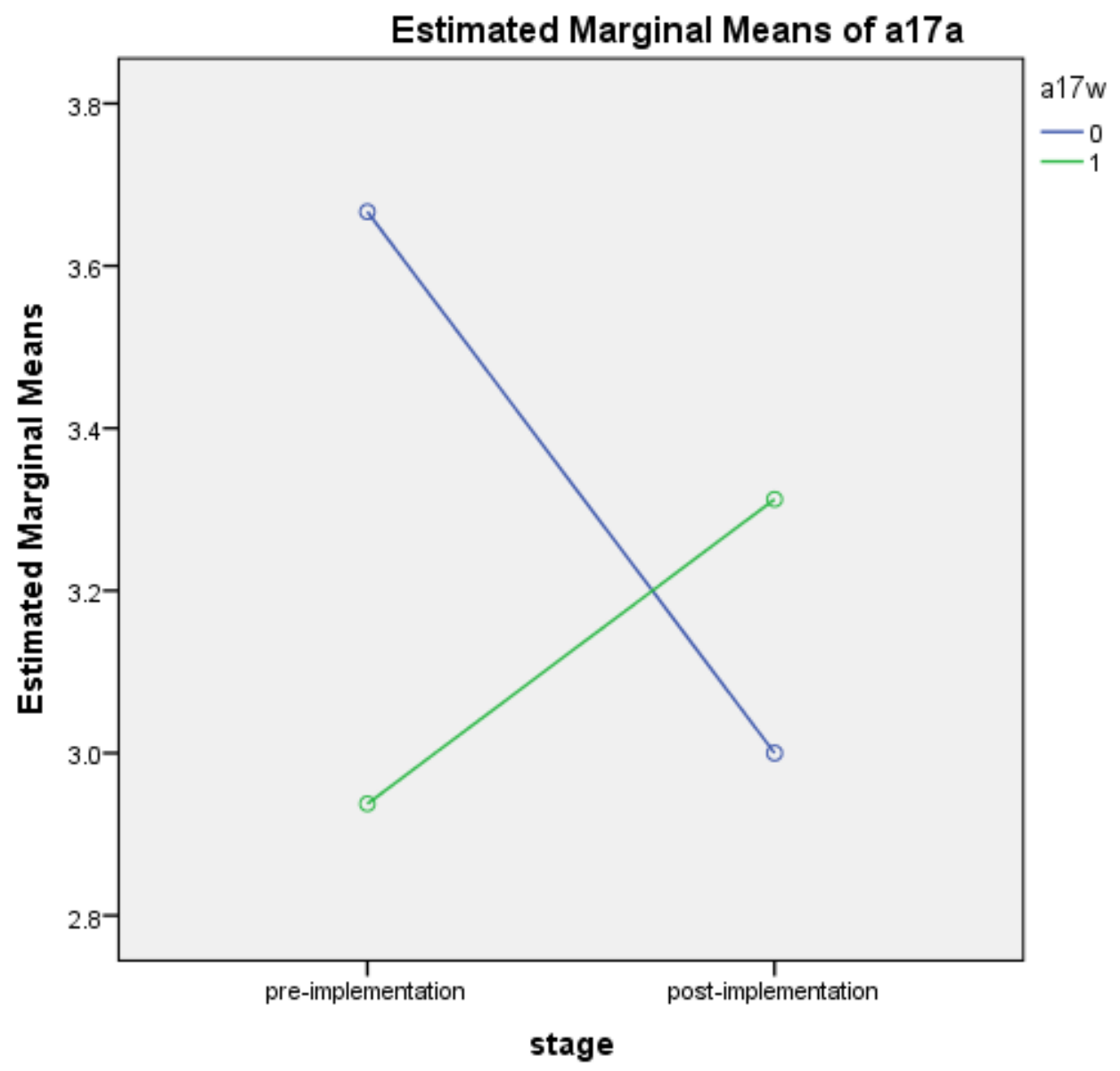

Figure 4.1 An illustration of the interaction between stages and perceived benefit for 'Ability to use Information Technology effectively' 


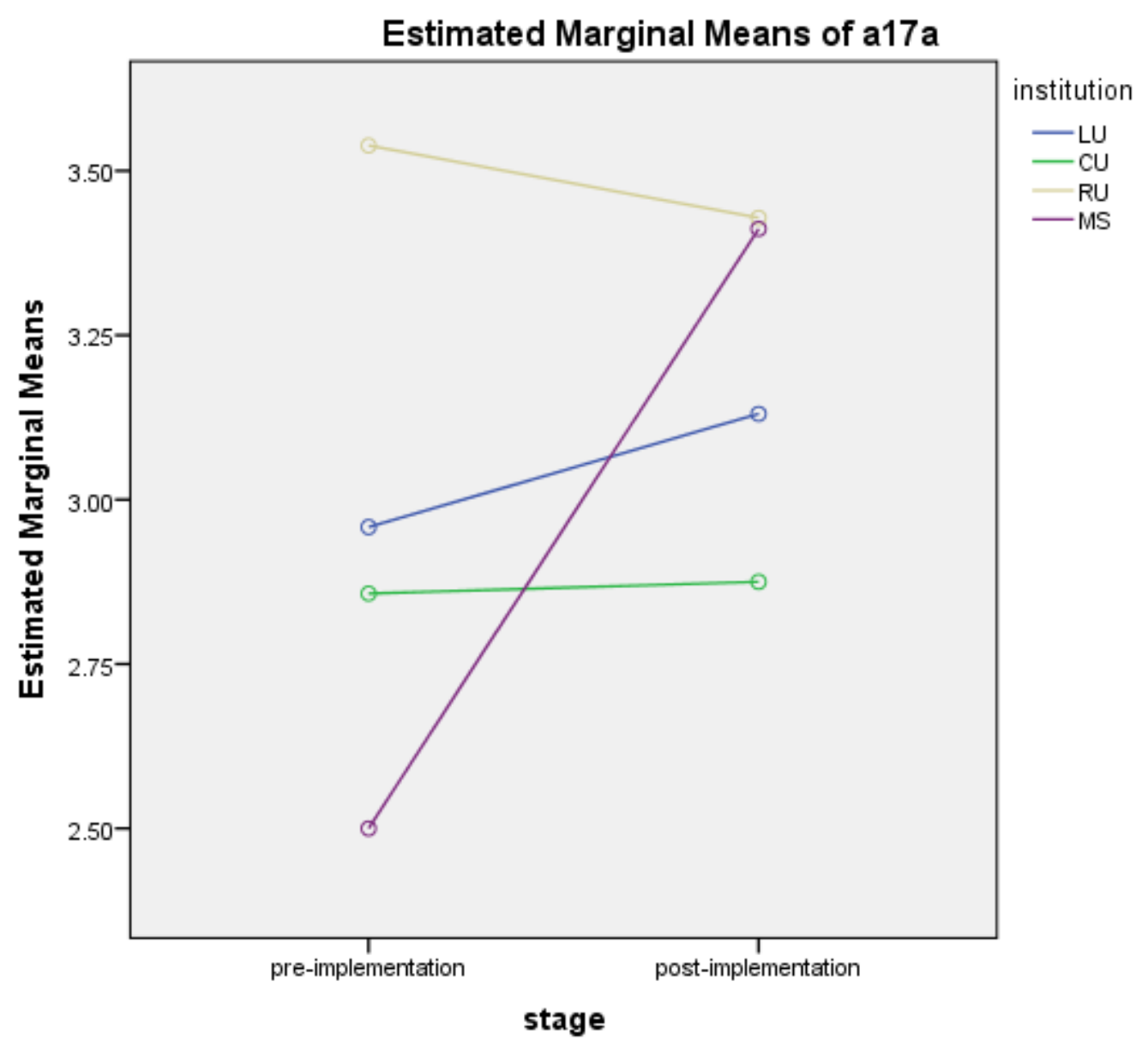

Figure 4.2 An illustration of the interaction between stages and discipline groups for 'Ability to use Information Technology effectively' 


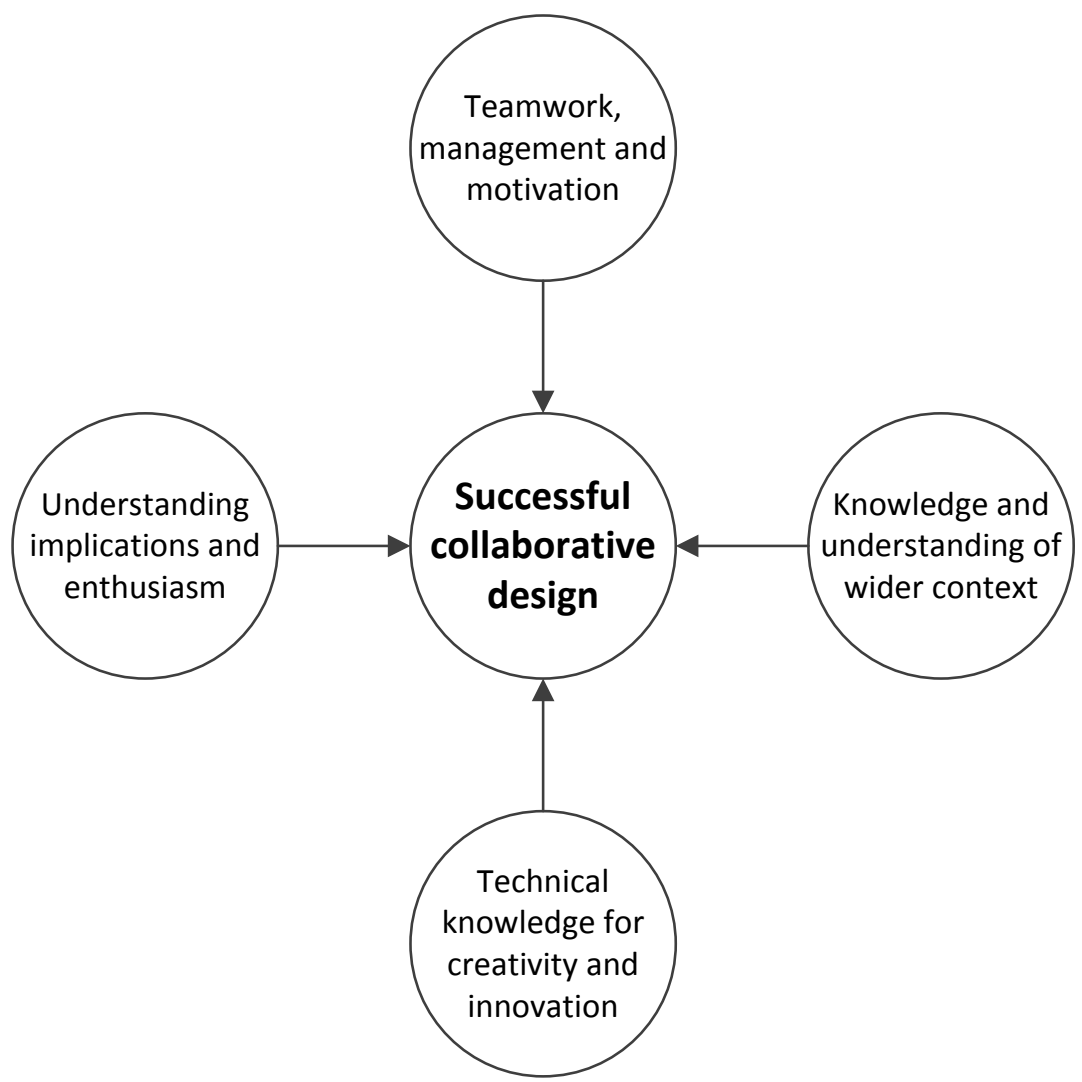

Figure 4.3 Components of required attributes for successful collaborative design 
Table 4.1 The results of statistical analysis of pre- and post-implementation scores and the influence of the perceived benefits and discipline groups

\begin{tabular}{|c|c|c|c|c|c|c|c|c|c|}
\hline \multirow[t]{2}{*}{ Code } & \multirow[t]{2}{*}{ Skills/attributes/qualities } & \multicolumn{2}{|c|}{ Average score } & \multirow[t]{2}{*}{ Difference } & \multirow{2}{*}{$\begin{array}{l}\text { Ranking of the } \\
\text { most } \\
\text { improvement }\end{array}$} & \multirow{2}{*}{$\begin{array}{c}\text { t-test } \\
\text { (Sig, 2-t) }\end{array}$} & \multirow{2}{*}{$\begin{array}{l}\text { ANOVA } \\
\text { (Sig.) }\end{array}$} & \multicolumn{2}{|c|}{ Two-way ANOVA } \\
\hline & & pre & post & & & & & $\begin{array}{l}\text { Stages vs } \\
\text { belief }\end{array}$ & $\begin{array}{l}\text { Stages vs } \\
\text { disciplines }\end{array}$ \\
\hline A01 & $\begin{array}{l}\text { Ability to demonstrate sound } \\
\text { specialist/discipline knowledge }\end{array}$ & 2.81 & 3.02 & 0.21 & 13 & $0.087^{*}$ & $0.000 * *$ & 0.611 & 0.497 \\
\hline A02 & $\begin{array}{l}\text { Ability to demonstrate understanding of } \\
\text { external constraints }\end{array}$ & 2.81 & 3.06 & 0.25 & 9 & $0.021 * *$ & $0.000 * *$ & 0.171 & 0.795 \\
\hline A03 & $\begin{array}{l}\text { Ability to demonstrate business and } \\
\text { management techniques }\end{array}$ & 2.72 & 2.67 & -0.05 & 25 & 0.675 & $0.000 * *$ & & 0.604 \\
\hline A04 & $\begin{array}{l}\text { Ability to demonstrate understanding of } \\
\text { professional and ethical responsibilities }\end{array}$ & 2.88 & 3.05 & 0.17 & 17 & 0.174 & $0.000 * *$ & & 0.385 \\
\hline A05 & $\begin{array}{l}\text { Ability to demonstrate understanding of the } \\
\text { impact of construction/ engineering solutions } \\
\text { on society }\end{array}$ & 2.74 & 3.03 & 0.29 & 4 & $0.039 * *$ & $0.000 * *$ & 0.384 & 0.351 \\
\hline A06 & $\begin{array}{l}\text { Ability to demonstrate an awareness of } \\
\text { relevant contemporary issues }\end{array}$ & 2.51 & 2.71 & 0.20 & 14 & 0.104 & $0.000 * *$ & & 0.499 \\
\hline A07 & $\begin{array}{l}\text { Ability to solve engineering and design } \\
\text { problems through creative and innovative } \\
\text { thinking }\end{array}$ & 2.73 & 3.02 & 0.29 & 4 & $0.038^{* *}$ & $0.000 * *$ & 0.642 & 0.330 \\
\hline A08 & $\begin{array}{l}\text { Ability to apply mathematical, scientific and } \\
\text { technological tools }\end{array}$ & 2.68 & 2.92 & 0.24 & 10 & $0.095 *$ & $0.000 * *$ & $0.000 * *$ & 0.137 \\
\hline A09 & $\begin{array}{l}\text { Ability to analyse and interpret data and, when } \\
\text { necessary, design experiments to gain new data }\end{array}$ & 2.47 & 2.69 & 0.22 & 11 & 0.104 & $0.000 * *$ & & 0.765 \\
\hline A10 & $\begin{array}{l}\text { Ability to maintain a sound theoretical } \\
\text { approach in enabling the introduction of new } \\
\text { technology }\end{array}$ & 2.49 & 2.69 & 0.20 & 14 & 0.131 & $0.000 * *$ & & 0.466 \\
\hline A11 & $\begin{array}{l}\text { Ability to apply professional judgement, } \\
\text { balancing issues of costs, benefits, safety, and }\end{array}$ & 2.85 & 2.90 & 0.05 & 23 & 0.673 & $0.000 * *$ & & 0.521 \\
\hline
\end{tabular}




\begin{tabular}{|c|c|c|c|c|c|c|c|c|c|}
\hline & quality & & & & & & & & \\
\hline A12 & Ability to assess and manage risks & 2.92 & 3.05 & 0.13 & 20 & 0.204 & $0.001 * *$ & & 0.579 \\
\hline A13 & $\begin{array}{l}\text { Ability to use a wide range of tools, techniques, } \\
\text { and equipment (including software) } \\
\text { appropriate to their specific discipline }\end{array}$ & 2.72 & 2.89 & 0.17 & 17 & 0.182 & $0.000 * *$ & & 0.227 \\
\hline A15 & $\begin{array}{l}\text { Ability to develop, promote and apply safe } \\
\text { systems of work }\end{array}$ & 2.78 & 2.87 & 0.09 & 22 & 0.499 & $0.001 * *$ & & 0.622 \\
\hline A16 & $\begin{array}{l}\text { Ability to communicate effectively, using both } \\
\text { written and oral methods }\end{array}$ & 3.03 & 3.25 & 0.22 & 11 & $0.058^{*}$ & $0.000 * *$ & & $0.002 * *$ \\
\hline A17 & $\begin{array}{l}\text { Ability to use Information Technology } \\
\text { effectively }\end{array}$ & 2.89 & 3.24 & 0.35 & 1 & $0.006 * *$ & $0.005^{* *}$ & $0.031 * *$ & $0.011^{* *}$ \\
\hline A18 & Ability to manage resources and time & 2.91 & 3.18 & 0.27 & 7 & $0.019 * *$ & $0.000 * *$ & 0.244 & 0.508 \\
\hline A19 & Ability to work in a multi-disciplinary team & 3.11 & 3.39 & 0.28 & 6 & $0.011^{* *}$ & $0.000 * *$ & 0.280 & 0.269 \\
\hline A20 & $\begin{array}{l}\text { Ability to undertake lifelong learning for } \\
\text { continuing professional development }\end{array}$ & 2.89 & 3.15 & 0.26 & 8 & $0.054^{*}$ & $0.000 * *$ & 0.315 & 0.782 \\
\hline A21 & Creative, particularly in the design process & 2.66 & 2.84 & 0.18 & 16 & 0.230 & $0.000 * *$ & & 0.515 \\
\hline A22 & $\begin{array}{l}\text { Analytical in the formulation and solutions of } \\
\text { problems }\end{array}$ & 2.67 & 2.97 & 0.30 & 3 & $0.012^{* *}$ & $0.000 * *$ & $0.002 * *$ & 0.287 \\
\hline A23 & $\begin{array}{l}\text { Innovative, in the solution of engineering } \\
\text { problems }\end{array}$ & 2.71 & 2.87 & 0.16 & 19 & 0.253 & $0.000 * *$ & & 0.286 \\
\hline A24 & Self-motivated & 3.27 & 3.31 & 0.04 & 24 & 0.730 & $0.000 * *$ & & $0.036 * *$ \\
\hline A25 & $\begin{array}{l}\text { Independent of mind, with intellectual integrity, } \\
\text { particularly in respect of ethical issues }\end{array}$ & 2.79 & 3.11 & 0.32 & 2 & $0.018^{* *}$ & $0.000 * *$ & 0.417 & 0.476 \\
\hline A26 & $\begin{array}{l}\text { Enthusiastic, in the application of their } \\
\text { knowledge, understanding and skills in pursuit } \\
\text { of the practice of engineering }\end{array}$ & 2.93 & 3.06 & 0.13 & 20 & 0.299 & $0.000 * *$ & & 0.925 \\
\hline
\end{tabular}

Note: ${ }^{*}$ significant at $10 \%,{ }^{* *}$ significant at $5 \%$ 
